\title{
DIGITAL ERA AND PROJECT MANAGER'S COMPETENCIES
}

\author{
Vladimir Obradović ${ }^{1}$, Alessandra Montenegro ${ }^{2}$, Dragan Bjelica ${ }^{3}$ \\ ${ }^{1,3}$ Faculty of Organizational Sciences, University of Belgrade, Serbia \\ ${ }^{2}$ Saga d.o.o., New Frontier Group, Belgrade, Serbia
}

\begin{abstract}
The paper presents project manager`s competencies that are critical for managing projects successfully in the digital era. In the beginning, there is literature review in the field of project manager`s competencies and then is presented research conducted on 52 project managers from the most renowned companies in Serbia. The research consists of two parts: the assessment of the competencies importance and the project managers self-assessment. The results showed that conceptual competencies (seeing the overall picture of the project and its connection with the environment, coordination of all elements of the project and having a vision) and relationships with people, are the most critical competencies that project managers should have. Technical skills are still significant but to a lesser extent. Regarding the possession of specific competencies, respondents have conceptual, political and human competencies. Thus, the digital age causes shifting from technical to soft skills such as analytical skills, decision making and working with people.
\end{abstract}

Key words: Competences, digital era, project manager, leader.

\section{INTRODUCTION}

New technologies are transforming the world, redefining customer expectations, enable the business to fulfil customer requirements and changing the way people live and work. Digital transformation has enormous potential to improve customers` lives. Cheaper and better technology make the world more connected: 8 billion devices are currently connected to the Web, and predictions are that the number reached 1 trillion in 2030. (World Economic Forum, 2016). Trends like Artificial Intelligence, Big Data, IoT, robots, drones and social networks transforming existing industries. Survival in the digital age has become a huge challenge for almost all enterprises. To be successful enterprises must become digital, create a digital business, improve operations, establish new KPIs and adopt new skills and knowledge. The vast majority of organizations do their business through projects. Project Management Institute defines a project as a temporary endeavour taken for producing a unique product, services or result (PMI, 2008). Application of project management in organizations improves effectiveness, efficiency, flexibility, quality, customer satisfaction, etc. Because of the project management's great importance and more challenging contemporary environment conditions, the great attention is directed to the central figure of the project - Project Manager. Project manager`s duty is to ensure achieving project objectives. New project management methodologies require new managerial skills (Kostic, 2017). The uniqueness of each project makes a difficult project manager role and requires a variety of competences from him. Numerous studies are undertaken to find a project manager most desired skill. Labour market is changing developing new gaps (Obradovic, Mitrovic, \& Pavicevic, 2017). Recent IT labor market analysis from CEB (2014) reveals that "IT project manager" is the most difficult-to-fill IT role globally. This comes as no surprise to IT and project management leaders who have consistently struggled to find the right talent to oversee their most critical projects and programs. Specific proffesions i.e. engineers hace substantial technical knowledge but lack project management competences (Semolic, Jovanovic, Kovacev, \& Obradovic, 2008). As

Corresponding author. Email: alessandramontenegro9@gmail.com

ISSN 2560-4961(online)

(C) 2018 IPMA Serbia

doi: 10.18485/epmj.2018.8.1.1 
organizations strive to digitize, the challenge of finding skilled IT project managers will only increase. The type of work that supports the typical organization's digitization ambitionsrapid, often iterative, and typically involving new technologies or processes-is the type of work that the average, the process-focused project manager isn't well equipped to handle.

The purpose of this paper is to present project manager competency research, conducted on 52 project managers from well-known companies.

\section{LITERATURE REVIEW}

This chapter examines the previous studies based on project managers' competencies. Katz (1974) is one of the pioneers who investigated effective managerial skills. He examined the skills, which executives exhibit to carry out their jobs effectively. He suggested three basic developable skills called (1) technical, (2) human, and (3) conceptual. He defines technical skill as the "specialized knowledge, analytical ability within that specialty, and facility in the use of the tools and techniques of the specific discipline", human skill as "the ability to work effectively as a group member and to build cooperative effort within the team", and conceptual skill as the "ability to see the enterprise as a whole including recognising how the various functions depend on one another and how changes in one part can affect all the others" (Katz, 1974: pp. 91, 93). A study by Peterson and Fleet (2004) demonstrated the profound impact of Katz's work on the management field. They examined 15 management principles books published in the mid-1980s and 15 management textbooks published in early 2000. The result indicated that "Katz's work was specifically referenced by almost all of the early works and by most of the more recent books".

Another study was conducted by El-Sabaa (2001) who explored the skills of the ideal project manager in Egypt. El-Sabaa utilized Katz's (1974) three-skill approach and developed a list of 18 characteristics of effective project managers, which he clustered into three-skill categories, namely (1) human skill (mobilizing, communication, coping with situations, delegating authority, political sensitivity, high self-esteem, and enthusiasm), (2) conceptual and organizational skill (planning, organizing, strong goal orientation, ability to see the project as a whole, ability to visualize the relationship of the project to the industry and the community, and strong problem orientation), and (3) technical skill (special knowledge in use of tools and techniques; project knowledge; understanding methods, processes, and procedures; technology required; and skills in use of computer).

Lei and Skitmore (2004) surveyed in South East Queensland, Australia, and identified essential skills that project managers should possess for the future. The skills identified are (1) technical skill, (2) people skills, (3) legal understanding, (4) client related skill, (5) stakeholders management skill, (6) cost management skill, (7) computing skill, (8) risk management skill, (9) time management skill, (10) coaching skill, (11) networking skill, and (12) business knowledge.

Kerzner (2009) listed ten required skills for project managers: (1) team building, (2) leadership, (3) conflict resolution, (4) technical expertise, (5) planning, (6) organisation (defining the reporting relationships, responsibilities, lines of control, and information needs), (7) entrepreneurship (understanding of general management such as economic considerations, customer satisfaction, and future growth), (8) administration, (9) management support (stakeholder management), and (10) resource allocation.

In the PMBOK guide, Project Management Institute (PMI, 2008) acknowledges the importance of technical, interpersonal, and conceptual skills for effective project managers. PMI (2008) explained further on the interpersonal skills and described eight essential interpersonal skills: (1) leadership (focusing the efforts of a group of people to achieve a common goal and team facilitation), (2) team building (helping a group of individuals to work interdependently with each other), (3) motivation (providing what people value the most to create an environment to achieve project objectives), 
communication (be aware of communication styles of others, managing various communication channels, and listening), (5) influencing (using power and strategies to get others to cooperate towards common goals), (6) decision making (considering various factors in making decisions), (7) political and cultural awareness (recognizing project politics, using power appropriately to manage the project, and managing cultural diversity to create an environment of trust), and (8) negotiation (discussing with other parties to compromise or reach an agreement).

IPMA ICB defines the competencies needed by individuals working in project management. According to ICB, the competencies in the project environment are divided into the following three categories (ICB, 2015): (a)People - Personal and interpersonal qualities required for managing projects; (b)Practice Competencies related to technical aspects of project management; (c)Perspective Competitive Competencies Required within a Specific Environment.

Sunindijo and Zou (2011) were researching 16 studies and acknowledged four sets of essential skills for project managers called CHPT to construct, in which $\mathrm{C}$ stands for conceptual skill, $\mathrm{H}$ for human skill, $\mathrm{P}$ for political skill, and T for technical skill. Katz's (1974) work serves as the foundation in the development of the CHPT construct but authors also proposed political skill as an additional skill essential for project managers because political issues have become an integral part in project management. Pinto (2000) explained that political processes dominate in the field of project management. Project managers often do not have a stable base of power thus they have to influence others to secure resources from other departments to achieve project success. Many successful project managers have understood the importance of maintaining strong political ties in their organizations as a method to attain project success. They are aware that politics, used wisely, can have a significant positive impact on the implementation of their projects (Pinto, 2000).

CHPT concept was used as a base for the following research and will be presented in the following chapter.

\section{IMPLEMENTATION OF THE STUDY}

In the previous chapter was shown competencies' classification into four categories: technical, human, conceptual and political. The aim of the conducted survey was to find: 1) what skills from the framework 1 are the most important and 2) to what extent project manager possess these skills.

The questionnaire had 38 questions classified in 3 groups: (a) 6 general questions (gender, years of work experience, industry in which PM works,etc.), (b) 16 questions that evaluate importance of each skill (from 1 to 5) and (c) 16 questions that required project manager's self-assessment about skills in the previous charter.

The skills examined in the second and third part of the questionnaire were identical, but in the second part the question was "To what extent do you consider that certain skill is significant?", While in the third part the question was "To what extent do you think you possess a certain skill?"

Participants in the research were 52 project managers from the most eminent companies in Serbia (Saga, Asseco, Kombank, Telekom, Delta Holding, ComTrade, AirSerbia, etc.). $25 \%$ of the total number of respondents were project managers with over ten years of experience, $34.4 \%$ have experienced between 5 and ten years, while $40.4 \%$ were respondents with less than five years experience. 


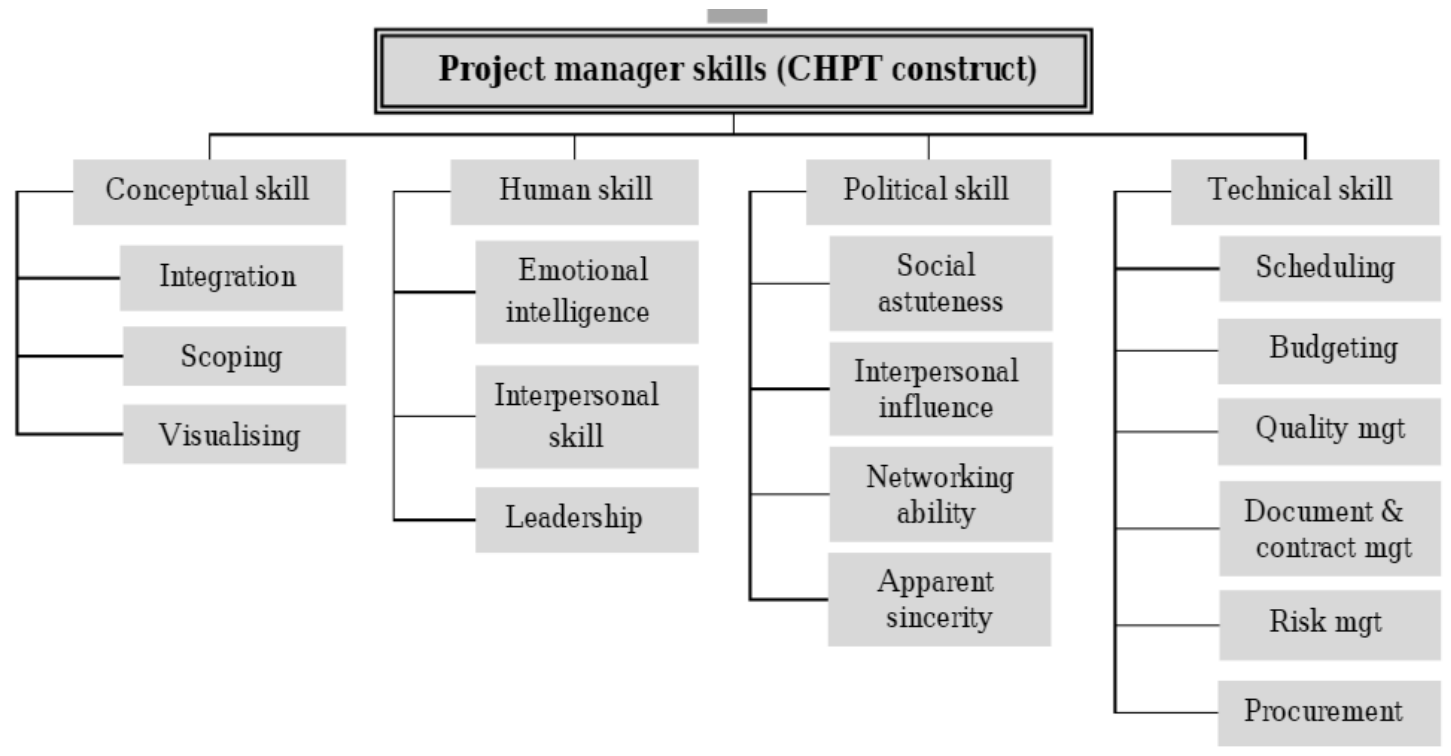

Figure 1: Theoretical framework of the essential project manager skills (CHPT construct)

At all of the respondents, years of experience in project management are less than a year of total work experience. $17.3 \%$ Have over ten years of experience, $11.5 \%$ between 5 and ten years, while $71.2 \%$ of respondents have less than five years of experience in project management. The fact that most project managers have less than five years of experience in project management, even though they have more years of service, indicates that individuals have changed positions in the past years and transferred to project managers. The demand for this profession is growing. It can be explained by the company's decisions to manage projects, recognizing the connection between projects and achieving strategic goals, and in no small extent forming project management sectors.

The proportion of men and women in the research is approximately equal, $51.9 \%$ were male respondents, and $48.1 \%$ were women. It can be noticed that $71.2 \%$ of respondents predominate project managers from the IT industry.

\section{DISCUSSION AND CONCLUSION}

As it was mentioned before, the research consists of 2 parts: (1) assessment of the significance of specific skills and (2) assessment of possession of the certain competences.
Regarding the first part, project managers assessed that project scope is at the first place by its importance. The project scope is the ability to determine and control what should be involved in the project and what not. At the second place are interpersonal skills and project integration that have the same average value. Interpersonal skills concern the manager's ability to communicate with different people effectively. Project integration is the ability to identify, define, combine, integrate, and coordinate the elements and resources of a project.

Considering that the project integration and the project scope are the skills from a conceptual competences group, it can be concluded that in the opinion of project managers, conceptual competences are the most important competences that they should possess. Calculating the average value of each category, the following result is obtained.

Table 1: Rank of competencies according to the importance

\begin{tabular}{|l|l|c|}
\hline & \multicolumn{1}{|c|}{$\begin{array}{c}\text { Competency } \\
\text { category }\end{array}$} & $\begin{array}{c}\text { Average } \\
\text { value }\end{array}$ \\
\hline 1. & Conceptual & 4,67 \\
\hline 2. & Human & 4,52 \\
\hline 3. & Political & 4,44 \\
\hline 4. & Technical & 4,20 \\
\hline
\end{tabular}


Therefore, it can be concluded that the conceptual skills according to the opinion of the respondents are the most important for the project managers. Then follow human and political, while the importance of the technical skills of project managers is emphasized to a minimum.

The second part of the research involved the self-assessment of the project managers. Each respondent rated the extent to which he thinks he possesses specific skills. The majority of respondents consider that they possess good interpersonal skills. Social intelligence and networking skills as representatives of political skills are at the second and third place. Also, integrity as another skill in the category of political takes the 5th place. It can be noted that respondents consider that they have a great deal of political competence.

Therefore, on the overall sample, the competences possessed by respondents are in the following order:

Table 2: Rank of competencies owned by respondent

\begin{tabular}{|l|l|c|}
\hline & $\begin{array}{c}\text { Competency } \\
\text { category }\end{array}$ & Average \\
\hline 1. & Conceptual & 4,173 \\
\hline 2. & Political & 4,173 \\
\hline 3. & Human & 4,166 \\
\hline 4. & Technical & 3,66 \\
\hline
\end{tabular}

It can be concluded that the respondents estimated that they possessed equally political and conceptual skills. There was a difference between project managers with less than 10 and over ten years of experience. The following table shows the difference.

Table 3: Difference between young and older project managers

\begin{tabular}{|c|c|}
\hline \multicolumn{2}{|c|}{$\begin{array}{l}\text { Years of experience in project } \\
\text { management }\end{array}$} \\
\hline Less than ten years & More than ten years \\
\hline $\begin{array}{l}\text { 1. Interpersonal } \\
\text { skill }\end{array}$ & $\begin{array}{l}\text { 1. Project } \\
\text { integration }\end{array}$ \\
\hline 2. Social astuteness & 2. Project scope \\
\hline 3. Networking & 3. Visioning \\
\hline
\end{tabular}

It is interesting that project managers with less than ten years of experience possess a great deal of political and interpersonal skills. Conceptual skills are not yet sufficiently developed in them. In contrast to them, senior managers mostly possess the conceptual skills behind which are political and interpersonal skills.

The significance of conceptual competences is strongly emphasized by all authors in the analyzed literature. It has also been established that the possession of these competences is more present in respondents with more extended experience in project management, while younger respondents have more human and political skills. The importance of technical skills in project management is at the last level when looking at the whole sample, but it is a positive phenomenon that in industries (telecommunications and banking) where the respondents assessed that specific technical skills are important, the same and possess.

Therefore, relationships with people and the overall picture of the project and its connection with the environment are the most essential skills of project managers in the digital era. Individuals and organizations increasingly understand the importance of soft skills of project managers and invest in their development. There is no longer such a significant technical knowledge of human, political, and conceptual skills. Digital transformation with new technologies, new business models, increased individualization and integration of virtuality and reality outperform the initial information technology capabilities of the 20th century, and project managers, project methodology experts, project management departments and leading associations have to respond to this change in order to ensure successful project management in the digital era. 


\section{REFERENCES}

CEB (2014), Developing the Entrepreneurial Skill of Project Managers, taken from https://www.pmiwdc.org/sites/default/file s/presentations/\%5Bsite-dateyyyy $\% 5 \mathrm{D} \% 5 \mathrm{~B}$ site-datemm\%5D/PMIW_PMTools_Presentation _20140617.pdf, date accessed: 21.08.2018.

El-Sabaa, S. (2001). The skills and career path of an effective project manager. International Journal of Project Management, Vol. 19, No. 1, pp.1-7.

Individual Competence Baseline for Project, Programme and Portfolio Management, (2015). International Project Management Association (IPMA).

Katz, R. L. (1974). Skills of an Effective Administrator, Harvard Business Review. Sep-Oct, pp. 91-93.

Kerzner, H. (2009). Project Management: $A$ System Approach to Planning, Scheduling, and Controlling, Tenth Edition, Hoboken, N.J.: Wiley.

Kostic, M. (2017). Challenges of Agile Practices Implementation in The Medical Device Software Development Methodologies, European Project Management Journal, Vol. 7, Issue 2, pp. 36-44.

Lei, W. W. S., \& Skitmore, M. (2004). Project management competencies: A survey of perspectives from project managers in South East Queensland. Journal of Building and Construction Management, Vol. 9, No. 1, pp.1-12

Obradovic, V., Mitrovic, Z., \& Pavicevic, M. (2017). Millennials vs. Baby Boomers in project management: Education and training gap, 12th International Scientific and Technical Conference on Computer Sciences and Information Technologies (CSIT), IEEE, 10.1109/STCCSIT.2017.8099422, 978-1-5386-1639-0, 2017.

Peterson, T. O., \& Fleet, D. D. V. (2004). The ongoing legacy of R.L. Katz: an updated typology of management skills, Management Decision, Vol. 42, No. 10, pp.1297-1308.

Pinto, J. (2000). Understanding the Role of Politics in Successful Project Management, International Journal of Project Management, 18(2):85-91

Project Management Institute (2008). A Guide to the Project Management Body of Knowledge: PMBOK Guide, Fourth Edition, Pennsylvania: USA.

Semolic, B., Jovanovic, P., Kovacev, S., \& Obradovic, V. (2008). Improving Repair Management of Bucket Wheel Excavator SRs1200 by Application of Project Management Concept, Journal of Mechanical Engineering, vol. 54 issue 78, 2008, ISSN: 0039-2480. pgs. 565-573.

Sunindijo, R. Y., \& Zou, P. X. W. (2011). CHPT construct: essential skills for construction project managers. International Journal of Project Organisation and Management, 3(2), 139-163

World Economic Forum (2016). The Fourth Industrial Revolution: what it means, how to respond?, taken from https://www.weforum.org/agenda/2016/0 $1 /$ the-fourth-industrial-revolution-whatit-means-and-how-torespond/,pristupljeno 27.08.2018 